Journal of MMIJ Vol.124 p.659-662(2008)

(C)2008 The Mining and Materials Processing Institute of Japan

論 文

Original Paper

\section{ポリエチレンによる石膏の高温還元の反応過程 *}

\title{
Reduction Process of Gypsum with Polyethylene at High Temperature
}

\author{
by Koji UOTANI ${ }^{\mathrm{a}}$, Shigeru UEDA ${ }^{\mathrm{b}}$, Katsunori YAMAGUCHI ${ }^{\mathrm{c}}$ and Takashi OKURA ${ }^{\mathrm{d}}$
}

a. Graduate Student, Faculty of Engineering, Iawate University

b. Institute of Multidisciplinary Research for Advanced Materials, Tohoku University

c. Faculty of Engineering, Iawate University (Corresponding author E-mail: benko@iwate-u.ac.jp)

d. Venture Business Laboratory, Akita University

\begin{abstract}
Most of waste plaster board, which contains gypsum has been buried in the landfill. However, this treatment of waste gypsum board is becoming a serious problem due to lack of landfill capacity, and secondary pollution by toxic substance. In this study, we focused a recycle of calcium resources as $\mathrm{CaO}$ or $\mathrm{CaS}$ from the waste gypsum, and developed a reduction process of the gypsum using plastics at high temperature. Reduction behavior of $\mathrm{CaSO}_{4}$ by Polyethylene at temperature from 1273 to $1573 \mathrm{~K}$ was studied with gravimetry and X-ray diffraction analysis. From the experimental results, we found that increasing $\mathrm{CaSO}_{4}-\mathrm{CH}_{2}$ gas interface tend to advance the reduction of $\mathrm{CaSO}_{4}$. Furthermore, direct formation of $\mathrm{CaS}$ from $\mathrm{CaSO}_{4}$ was observed only at temperature of $1273 \mathrm{~K}$ without an intermediate compounds stage, and the reduction sequence was $\mathrm{CaSO}_{4} \rightarrow \mathrm{CaO} \rightarrow \mathrm{CaS}$ at temperatures higher than $1373 \mathrm{~K}$. Finally, the sequence of reduction process for $\mathrm{CaSO}_{4}$ was discussed on the potential diagram of the Ca$\mathrm{S}_{2}-\mathrm{O}_{2}$ system.
\end{abstract}

KEY WORDS: Waste Gypsum, Waste Plaster Board, Waste Plastics, Reduction, Recycle

\section{1.はじめに}

石膏ボードは，石膏 $\left(\mathrm{CaSO}_{4}\right)$ を芯材とし両面をボード用原紙で 被覆した内装材で, 現在, 国内では年間 500 万トン程度が生産さ れている。これらの石膏ボードは, 数十年後に建築物の解体に伴 い, 廃棄物として処分されることになる。解体に伴い排出される 廃石膏ボードは, 付着した紙などの異物の分別が困難であるため, また分別にはコストが掛かるために，現状では，製造時における 自家発生や新築時の廃材の一部がリサイクルされている程度で, 生産量に占めるリサイクル材の割合は $5 \%$ 程度と極めて低いのが 現状である ${ }^{1)}$ 。今後，建築物の解体による年間 150 ～ 200 万トン 程度の廃石膏ボードが排出されると見込まれており 1), これらは 最終処分場で処分されることになる。廃石膏ボードを埋め立て処 分した場合，有毒である硫化水素が生成する場合があり，処分場 ではそのことが原因となり作業員が死亡する事故が発生してい る。そのため, 安定型産業廃棄物として扱われてきた廃石膏ボー ドは, 平成 18 年より管理型産業廃棄物として扱われることとなっ $た^{2)}$ 。国内に現存する管理型の最終処分場の数とその処理容量は

* 2008 年 6 月 19 日受付 10 月 6 日受理

1. 岩手大学大学院 学生

2. 普通会員 東北大学多元物質科学研究所 助教

3. 普通会員 岩手大学工学部材料物性工学科 教授

4. 普通会員 秋田大学ベンチャービジネスラボラトリー＼cjkstart教授

[ 著者連絡先 ] FAX : 019-621-6367 (岩手大・山口) E-mail : benko@iwate-u.ac.jp

キーワード：廃石膏ボード，プラスチック，リサイクル，廃棄物処理，還 元処理
限られており，処分場の延命化を図るうえで，石膏の無害化と再 資源化が望まれている。

著者らは，還元剤として廃プラスチックを用い，廃石膏ボード を高温で還元することにより, $\mathrm{CaO}$ や $\mathrm{CaS}$ などのカルシウム資 源として再生することが可能か調べる目的で, ポリエチレン試薬 を用いて実験を行った。その結果, $\mathrm{CaSO}_{4}$ とポリエチレン $\left(\mathrm{CH}_{2}\right.$ で 1 モルとして換算) をモル比で $1: 3$ として混合し, アルゴン 雰囲気下で $1473 \mathrm{~K} ， 2 \mathrm{~h}$ 程度加熱すると $\mathrm{CaO}$ に，また， $\mathrm{CaS}$ が安 定するような $\log p_{\mathrm{S}_{2}}$ と $\log p_{\mathrm{O}_{2}}$ に炉内を制御することで $\mathrm{CaS}$ に還 元できることを報告した ${ }^{3)}$ 。本研究ではこれまでの研究に基づき, $\mathrm{CaSO}_{4}$ とポリエチレン分解ガスの反応面積を増加させることによ り短時間で $\mathrm{CaSO}_{4}$ を還元することが可能か，また，より低温度 で $\mathrm{CaSO}_{4}$ をポリエチレンで還元し $\mathrm{CaO}$ や $\mathrm{CaS}$ を生成することが 可能か, $\mathrm{CaSO}_{4}$ の還元に及ぼす温度の影響について調べた。得ら れた結果に基づいて, $\mathrm{CaSO}_{4}$ の還元過程について考察してみた。

\section{2. 実 験 方 法}

実験方法の概略は既報で報告した ${ }^{3)}$ 。プラスチックとして，直 径 $3 \mathrm{~mm}$ 程度の粒状の低密度ポリエチレン試薬を用いた。 $\mathrm{CaSO}_{4}$ は焼石膏 $\mathrm{CaSO}_{4} \cdot 1 / 2 \mathrm{H}_{2} \mathrm{O}$ 試薬を予め $1573 \mathrm{~K}$ で $1 \mathrm{~h}$ 加熱し, 無水 $\mathrm{CaSO}_{4}(136.1 \mathrm{~g} / \mathrm{mol})$ として実験に供した。ポリエチレン, $\left(\mathrm{CH}_{2}\right) \mathrm{n}$ （ポリエチレンの基本分子が $\mathrm{CH}_{2}$ であること，また $\mathrm{CaSO}_{4}$ と反 応する乾溜ガスの分子を $\mathrm{CH}_{2}$ と見なし, 本研究ではポリエチレ ン $1 \mathrm{~mol}$ の分子量を $14.0 \mathrm{~g} / \mathrm{mol}$ で換算した）と $\mathrm{CaSO}_{4}$ を目的の混 合比になるよう秤量, 配合し, 内径 $22 \mathrm{~mm}$, 深さ $30 \mathrm{~mm}$ のアルミ 


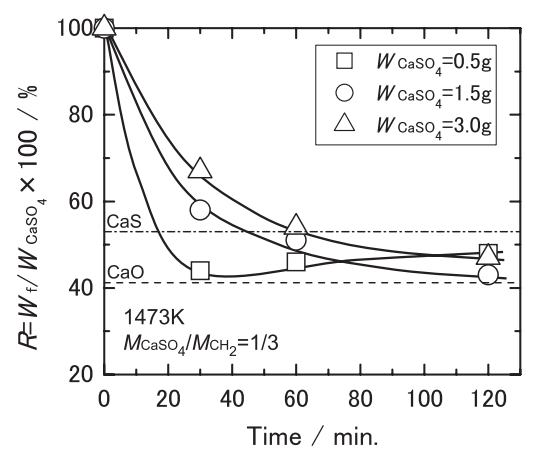

Fig.1 Effect of sample weight on the reduction rate of gypsum at $1473 \mathrm{~K}$ under an air atmosphere; $\left(M_{\mathrm{CaSO}_{4}} / M_{\mathrm{CH}_{2}}=1 / 3\right)$.

ナ製のルツボに充填した。試料はペレットに圧縮成型せずに，荷 重を加えることなくルツボに装入している。いずれの試料におい ても実験開始前のルツボ内の $\mathrm{CaSO}_{4}$ の見かけ密度は $1.2 \mathrm{~g} / \mathrm{cm}^{3}$ 程 度であった。このルツボには, 加熱時における分解したポリエチ レンのガスを滞留させるために, 直径 $1.5 \mathrm{~mm}$ 程度の小孔を有し たアルミナ製の蓋を載せている。試料を内径 $30 \mathrm{~mm}$, 長さ $500 \mathrm{~mm}$, 容量 $360 \mathrm{ml}$ 程度の石英製の反応管に装入し，目的温度 の炉内に反応管を設置し, 加熱, 保持した。所定の時間後, アル ゴンガスを吹き付けて試料を冷却した。実験後の試料の重量変化 ならびX 線解析の結果を JCPDS のデータ 4) と比較することによ り, 試料の同定を行った。

還元反応の時間を短縮することが可能か調べる実験では, $\mathrm{CaSO}_{4}$ と $\mathrm{CH}_{2}$ のモル比を $1: 3$ と固定し, $\mathrm{CaSO}_{4}$ の質量を $0.5 \sim 3.0 \mathrm{~g}$ と変化させ, 加熱時のポリエチレン乾留ガスとの反応面積を変化 させ $1473 \mathrm{~K}$ で実験を行った。また, $\mathrm{CaSO}_{4}$ の還元に及ぼす温度 の影響を調べる目的で, $\mathrm{CaSO}_{4}$ と $\mathrm{CH}_{2}$ のモル比を 1: 3, $\mathrm{CaSO}_{4}$ と $\mathrm{CH}_{2}$ の質量をそれぞれ $0.5,0.154 \mathrm{~g}$ と固定して, $1273 \sim 1573 \mathrm{~K}$ の温度範囲で試料を加熱した。なお，本実験は実際の操業を想定 し，アルゴンガス等の不活性ガスで試料系内を置換しておらず, 反応管には約 $360 \mathrm{ml}$ の空気が存在している条件で実験を行った。

\section{3. 実 験 結 果}

\section{3・1 $\mathrm{CaSO}_{4}$ とポリエチレン乾留ガスとの反応面積の影響}

いずれの温度の実験においても, 目的温度を達成した炉内に反 応管を設置し， $5 \mathrm{~min}$ 程度で反応管内は約 $773 \mathrm{~K}$ となり反応管上部 のガス導出管を目視によりポリエチレンの熱分解ガスの発生が確 認された。また, 約 $15 \mathrm{~min}$ 後には目標温度である $1473 \mathrm{~K} に$ 到達 した。実験終了後, 試料を肉眼で観察した結果, 固体炭素の未燃 物は観察されず，ポリエチレンは全て熱分解してガス化したもの と考える。

また，試料は多少の焼結は見られるものの，外観は白色であり 色の変化は認められなかった。

$\mathrm{CaSO}_{4}$ と $\mathrm{CH}_{2}$ のモル比を固定し, $\mathrm{CaSO}_{4}$ の質量を $3.0 \sim 0.5 \mathrm{~g}$ と変化することで, 熱分解ガスとの反応面積を変化させて実験を 行った場合の, 次式で定義される試料の質量変化率, $R(\%)$ と保 持時間の関係を Fig. 1 に示す。

$$
R(\%)=\left(W_{\mathrm{f}} / W_{\mathrm{CaSO}_{4}}\right) \cdot 100
$$

ここで, $W_{\mathrm{CaSO}_{4}}$ は実験前の $\mathrm{CaSO}_{4}$ 質量を, $W_{\mathrm{f}}$ は実験後の試料質 量を表す。図中の破線と一点鎖線はそれぞれ $\mathrm{CaSO}_{4}$ が全て $\mathrm{CaO}$ $(56.08 \mathrm{~g} / \mathrm{mol})$ または $\mathrm{CaS}(72.14 \mathrm{~g} / \mathrm{mol})$ に還元された場合の值を示 す。図に示されるように，いずれの質量においても加熱保持時間

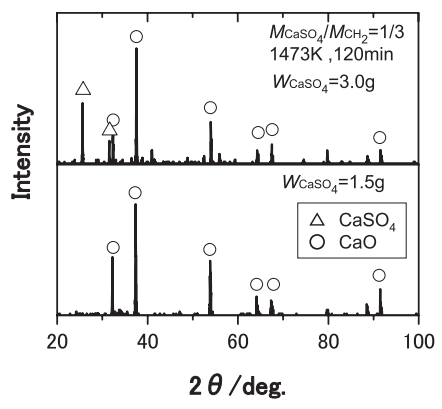

Fig.2 XRD patterns of products obtained from the reaction of $\mathrm{CaSO}_{4}$ and $\mathrm{CH}_{2}$ at $1473 \mathrm{~K}$ for 120 min under an air $\left(M_{\mathrm{CaSO}_{4}} / M_{\mathrm{CH}_{2}}=1 / 3, W_{\mathrm{CaSO}_{4}}=3.0 \mathrm{~g}\right.$ and $\left.1.5 \mathrm{~g}\right)$.

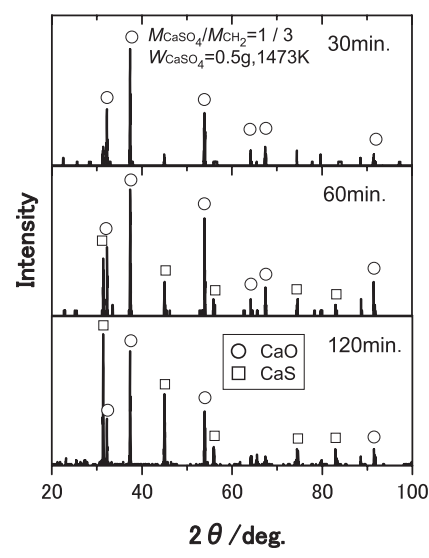

Fig.3 XRD patterns of obtained products at $1473 \mathrm{~K}$ under an air; $\left(M_{\mathrm{CaSO}_{4}} / M_{\mathrm{CH}_{2}}=1 / 3, W_{\mathrm{CaSO}_{4}}=0.5 \mathrm{~g}\right)$.

が増加するに伴い試料質量は減少する。これは，後述するX $\mathrm{X}$ 線 回折の結果から, $\mathrm{CaSO}_{4}$ が $\mathrm{CaO}$ および $\mathrm{CaS}$ に還元されたことに よる。試料質量が少ないほど, 寸なわち試料と乾留ガスの反応界 面積が増加するに伴い, 試料質量の減少速度は速くなることが分 かる。試料質量が $0.5 \mathrm{~g}$ の場合, $30 \mathrm{~min}$ 程度で $1.5 \mathrm{~g}$ の $120 \mathrm{~min}$ の值 と同程度まで質量は減少し，保持時間の経過と共に質量が若干増 加した。この理由についてはX 線回折の結果を用いて後述する。

初期 $\mathrm{CaSO}_{4}$ 質量を 3.0 と $1.5 \mathrm{~g}$ とし， $1473 \mathrm{~K}$ で $120 \mathrm{~min}$ 保持した 試料の X 線回折の結果を Fig. 2 に掲げる。 $3.0 \mathrm{~g}$ の試料では, 未 反応の $\mathrm{CaSO}_{4}$ の回折線が確認され, 完全に還元反応が進行して いないことが分かる。一方, $1.5 \mathrm{~g}$ の試料では, $\mathrm{CaO}$ の回折線の みが確認され, $\mathrm{CaSO}_{4}$ は $\mathrm{CaO}$ に還元されていることが分かる。 このことから, $\mathrm{CaSO}_{4}$ とポリエチレン乾留ガスの反応面積を増大 させることが, $\mathrm{CaSO}_{4}$ の還元を促進するうえで有効である。した がって, 本処理を行うにあたっては, 前処理として石膏ボードの 粉砕が重要であり, 反応炉として金属製錬や廃棄物処理で利用さ れる多段焙焼炉, 流動床炉, 回転炉など摚挥力のある炉が適する と考える。

Fig. 3 には， $0.5 \mathrm{~g}$ の $\mathrm{CaSO}_{4}$ を $1473 \mathrm{~K}$ で $30 ， 60 ， 120 \mathrm{~min}$ 反応さ せた際の X 線回折結果を示す。反応時間が $30 \mathrm{~min}$ の結果は $\mathrm{CaO}$ の回折線のみが観察されたが，60 と 120 min では $\mathrm{CaO}$ の他に $\mathrm{CaS}$ の回折線が存在している。60 と $120 \mathrm{~min}$ の比較に於いて, $120 \mathrm{~min}$ の $\mathrm{CaS}$ の第一ピーク強度が大きいことから， $0.5 \mathrm{~g}$ の試料の場合， $\mathrm{CaSO}_{4}$ は $\mathrm{CaO}$ に還元された後, 反応管内の気相中の $\mathrm{SO}_{2}$ や $\mathrm{H}_{2} \mathrm{~S}$ 等のイオウを含むガスと $\mathrm{CaO}$ が反応し, $\mathrm{CaO}$ より分子量の大き な $\mathrm{CaS}$ が生成されたものと考える。このことは Fig. 1 において, $0.5 \mathrm{~g}$ 試料の質量変化率が一度最小值を示した後, 再び増加寸るこ 


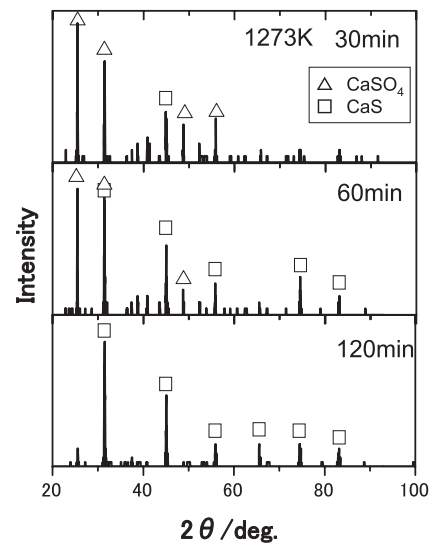

Fig.4 Results of XRD for products at $1273 \mathrm{~K}$ under an air; $\left(M_{\mathrm{CaSO}_{4}} / M_{\mathrm{CH}_{2}}=1 / 3, W_{\mathrm{CaSO}_{4}}=0.5 \mathrm{~g}\right)$.

とを良く説明できる。

\section{$3 \cdot 2$ 還元に及ぼす温度の影響}

$\mathrm{CaSO}_{4}$ 還元における温度の影響を調べる目的で, $\mathrm{CaSO}_{4}$ とポ リエチレンの質量をそれぞれ $0.5,0.154 \mathrm{~g}\left(M_{\mathrm{CaSO}_{4}} / M_{\mathrm{CH}_{2}}=1 / 3\right)$ と固 定し，1273〜1573K の温度範囲で試料を加熱した。

Fig. 4 に $1273 \mathrm{~K}$ で $30,60 ， 120 \mathrm{~min}$ 加熱保持した試料の X 線回 折の結果を示す。反応時間の増加に伴い $\mathrm{CaSO}_{4}$ の回折線強度が 減少し, $\mathrm{CaS}$ の強度が大きくなり，120min においては $\mathrm{CaS}$ の回 折線のみとなる。いずれの時間においても $\mathrm{CaO}$ の回折線は観察 されず，本実験条件下である $1273 \mathrm{~K}$ では， $\mathrm{CaSO}_{4}$ は $\mathrm{CaO}$ を生成 せずに直接 $\mathrm{CaS}$ に還元される。

また，1373〜 1573K で 60min 加熱保持した試料の X 線回折結 果をFig. 5 に示した。反応温度を $1373 \mathrm{~K}$ とした場合, $\mathrm{CaSO}_{4}$ の 回折線と共に $\mathrm{CaO}, \mathrm{CaS}$ の 3 相が共存することが特徴である。一 方， $1473 \mathrm{~K}$ 以上の温度では $\mathrm{CaSO}_{4}$ の回折線は見られず, $\mathrm{CaO}$ と $\mathrm{CaS}$ の 2 種類のカルシウム化合物の回折線のみが観察され，加熱 温度が高いほど $\mathrm{CaSO}_{4}$ の還元反応が促進されることが分かる。 $1373 \mathrm{~K}$ 以上のいずれの温度においても， $\mathrm{CaO}$ と $\mathrm{CaS}$ が存在して いるが，前述したように $\mathrm{CaSO}_{4}$ は $\mathrm{CaO}$ に還元された後，気相中 の $\mathrm{SO}_{2}$ や $\mathrm{H}_{2} \mathrm{~S}$ 等のイオウを含むガスと反応し, $\mathrm{CaS}$ が生成する ためと考える。これらの $\mathrm{CaSO}_{4}$ の還元過程については, 次の CaS-O 系ポテンシャル図でさらに考察する。

本実験の条件においては，低温でも $\mathrm{CaSO}_{4}$ を $\mathrm{CaS}$ に還元でき ることが分かった。 $\mathrm{CaS}$ は (2) 式の反応により, $\mathrm{H}_{2} \mathrm{~S}$ ガスの発生 を伴うものの室温でも容易に $\mathrm{CaO}$ にすることが可能である。

$$
\mathrm{CaS}+\mathrm{H}_{2} \mathrm{O}=\mathrm{CaO}+\mathrm{H}_{2} \mathrm{~S}(\mathrm{~g}) \uparrow
$$

一方， $\mathrm{CaSO}_{4}$ を乾式プロセスで直接 $\mathrm{CaO}$ に転換するためにはよ り高温であることが望ましいことが分かった。高温の達成には， プラスチックの燃焼熱を利用することも可能と考える。

\section{4. $\mathrm{CaSO}_{4}$ の還元過程に関する考察}

$1273 \sim 1573 \mathrm{~K}$ の温度範囲で, $0.5 \mathrm{~g}$ の $\mathrm{CaSO}_{4}$ を $0.154 \mathrm{~g}$ のポリエ チレンで還元した場合, $1273 \mathrm{~K}$ では $\mathrm{CaSO}_{4}$ は $\mathrm{CaO}$ を生成するこ となく直接 $\mathrm{CaS}$ に還元された。一方，1373K から 1573K の温度 範囲では, $\mathrm{X}$ 線回折の結果と試料重量の変化率を考慮すると, $\mathrm{CaSO}_{4}$ は一度 $\mathrm{CaO}$ に還元されてから $\mathrm{CaS}$ に変化していた。Fig. 6 に $1273 \sim 1573 \mathrm{~K}$ における Ca-S-O 系ポテンシャル図を示す5)。 ここで, $\mathrm{CaSO}_{4}, \mathrm{CaO}, \mathrm{CaS}$ 各固体の活量は 1 である。図に示さ れるように, 温度の上昇と共に $\mathrm{CaSO}_{4}-\mathrm{CaO}$ 及び $\mathrm{CaSO}_{4}-\mathrm{CaS}$ の境

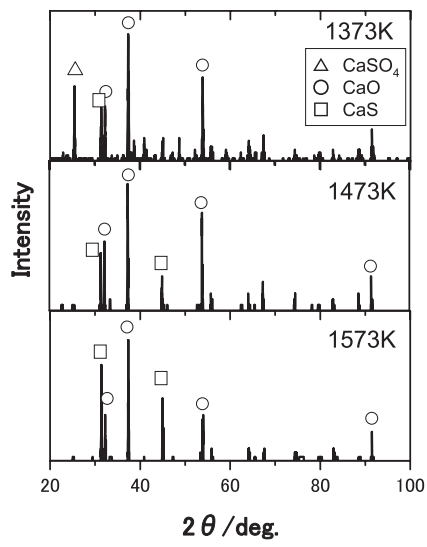

Fig.5 XRD patterns of products obtained from the reaction of $\mathrm{CaSO}_{4}$ and $\mathrm{CH}_{2}$ at temperatures from 1373 to $1573 \mathrm{~K}$ for 60 min under an air; $\left(M_{\mathrm{CaSO}_{4}} / M_{\mathrm{CH}_{2}}=1 / 3, W_{\mathrm{CaSO}_{4}}=0.5 \mathrm{~g}\right)$.

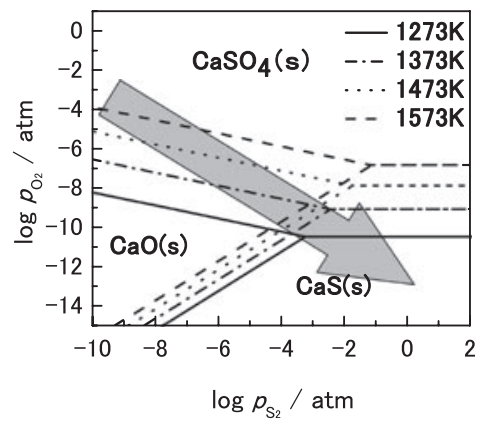

Fig.6 Potential diagrams of the $\mathrm{Ca}-\mathrm{S}_{2}-\mathrm{O}_{2}$ system

界は高 $\log p_{\mathrm{O}_{2}}$ 側へ移動し, $\mathrm{CaSO}_{4}$ は酸素ポテンシャルが高い領 域で安定となる。言い替えれば $\mathrm{CaSO}_{4}$ は温度が高いほど $\mathrm{CaO}$ や $\mathrm{CaS}$ に還元し易くなる。この傾向は本実験の結果と良く一致する。 また, 温度の上昇に伴い $\mathrm{CaO}$ と $\mathrm{CaS}$ の共存線は, $\log p_{\mathrm{O}_{2}}$ を一定 とすると若干ではあるが低 $\log p_{\mathrm{S}_{2}}$ 側へ移動するが, $\mathrm{CaSO}_{4}$, $\mathrm{CaO}, \mathrm{CaS}$ の 3 相が共存するポテンシャルは高 $\log p_{\mathrm{O}_{2}}$, 高 $\log p_{\mathrm{S}_{2}}$ へ移動するため, Fig. 6 に見られるように図のポテンシャル範囲 において, $\mathrm{CaO}$ の安定域は高温ほど広くなる。

本実験の $\mathrm{CaSO}_{4}$ とポリエチレンの反応は還元反応であり, 酸 素ポテンシャルは空気䨌囲気から低酸素ポテンシャルへ変化す る。一方, 一定の酸素ポテンシャルにおいて $\mathrm{CaS}$ はイオウポテ ンシャルが高い領域で安定する。実験開始時点における酸素とイ オウのポテンシャルは正確には分からないが, 実験初期の酸素ポ テンシャルは空気雰囲気 $p_{\mathrm{O}_{2}}=0.21 \mathrm{~atm}$ 程度で, イオウポテンシャ ルの低い領域においてから $\mathrm{CaSO}_{4}$ から $\mathrm{CaO}$ や $\mathrm{CaS}$ が生成するこ と，および $1273 \mathrm{~K}$ では $\mathrm{CaSO}_{4}$ から $\mathrm{CaS}$ が直接生成され，それ以 上の温度では $\mathrm{CaO}$ の生成を経由して $\mathrm{CaS}$ になることを考慮する と, 本実験条件下では $\mathrm{CaSO}_{4}$ の還元反応は Fig. 6 の矢印の方向 に反応が進んでいると考えられる。

熱力学データベース FactSage を用いて反応経路の算出を試み た ${ }^{5)}$ 。計算は, 本実験条件である全圧 $1 \mathrm{~atm}$ 下で $W_{\mathrm{CaSO}_{4}}(\mathrm{~s})=0.5 \mathrm{~g}$, 反応管容積である $V_{\text {air }}=380 \mathrm{ml}$ に対し, $\mathrm{CH}_{2}(\mathrm{~g})$ の量を $0.154 \mathrm{~g}$ ま で変化させて行った。Fig. 7 には 1 例として $1573 \mathrm{~K}$ の各ガス種の 分圧と酸素ポテンシャルの関係を示す。Fig. 7 に示されるように, $\mathrm{CH}_{2}$ (g) の量が増えるに伴い $\mathrm{CO}$ や $\mathrm{H}_{2}$ ガスの分圧が増加し, 系内 の酸素ポテンシャルは低くなる。一方, $\mathrm{S}_{2}$ ガスの分圧は酸素ポ テンシャルの増加に伴い増加し, $\log p_{\mathrm{O}_{2}}=-8$ 程度で減少する。 


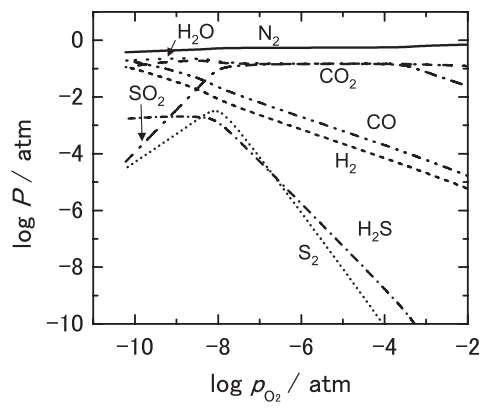

Fig.7 Partial pressure of gas species as a function of the oxygen potential at $1573 \mathrm{~K}$

これは $\mathrm{H}_{2}$ ガス分圧の増加により $\mathrm{H}_{2} \mathrm{~S}$ ガス種が優勢に存在するた めである。

また Fig. 8 には 1273 と $1573 \mathrm{~K}$ の反応経路を示した。計算され た $1273 \mathrm{~K}$ のポテンシャルの進行経路は, $\mathrm{CaSO}_{4}$ と $\mathrm{CaO}$ の共存線 に沿って $\mathrm{CaS}$ の安定領域に, $1573 \mathrm{~K} て ゙ は, ~ \mathrm{CaO}$ の安定領域を通 り $\mathrm{CaS}$ の生成域へ進む。計算は密閉系の值を示寸ものであり， 本実験の開放系と異なるものの計算結果は実験結果から考察され る反応経路と大変良い一致を示す。

\section{5.おわりに}

本研究では廃石亳ボードを廃プラスチックで $\mathrm{CaO}$ 等に高温で 還元するうえで, 還元反応の時間を短縮することが可能か, また, $\mathrm{CaSO}_{4}$ の還元に及ぼす温度の影響を, 試薬を用いて空気雾囲気下 で調べた。その結果,

・加熱時のポリエチレン乾留ガスと $\mathrm{CaSO}_{4}$ の反応面積を増加さ せることは還元を促進するうえで重要である。本実験条件では, $30 \mathrm{~min}$ 程度で $\mathrm{CaSO}_{4}$ を $\mathrm{CaO}$ に還元することができた。

・1273〜 1573K の温度範囲において, $\mathrm{CaSO}_{4}$ は低温で $\mathrm{CaS}$ を生

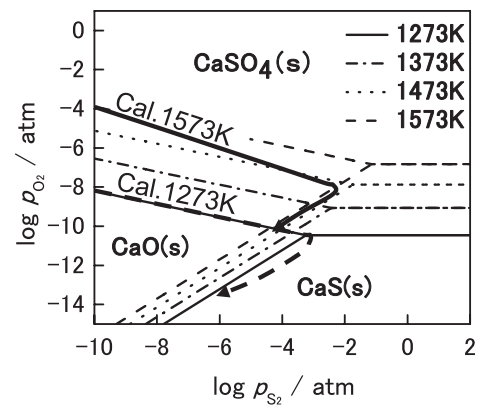

Fig.8 Reduction sequences of $\mathrm{CaSO}_{4}$ at 1273 and $1573 \mathrm{~K}$ in the potential diagram of the $\mathrm{Ca}-\mathrm{S}_{2}-\mathrm{O}_{2}$ system.

成しやすく, 温度の上昇と伴に $\mathrm{CaO}$ を生成しやすくなる。こ の傾向は Ca-S-O 系ポテンシャル図により理解される。

・本実験条件における $\mathrm{CaSO}_{4}$ の還元反応の反応経路は, $1273 \mathrm{~K}$ では $\mathrm{CaSO}_{4}$ から直接 $\mathrm{CaS}$ 老生成するの対し, $1373 \mathrm{~K}$ 以上の温 度では, $\mathrm{CaSO}_{4} \rightarrow \mathrm{CaO} \rightarrow \mathrm{CaS}$ に変化することが分かった。こ の反応経路は熱力学計算結果と良く一致する。

謝辞本研究の一部は, (財) 日本化学研究会の助成により 行われたものであることを付記し，謝意を表する。

\section{References}

1) For example; Report of Ministry of the Environment Government of Japan:Sekkoboud no Risaikuru no Suisin nikansuru Kentou Chousho, (2002), Sekkobodo-Kougyoukai: http:// www.gypsumboard-a.or.jp/

2) Notice of Ministry of the Environment Government of Japan: Kankyosanhatsu No.060601001, Sekkobodo kara Fuchakushiteir Kami wo Jokyo shitamonono Toriatukai ni Tsuite, (2006)

3) S.Ueda, Y.Hatakeyama, K.Yamaguchi, I.Nakamura and T.Okura: Journal of MMIJ, 122(2006), 456-461.

4) Joint Committee on Powder Diffraction Standard, 1601 Park Lane, Swarthmore, Pa. 19081.

5) C. W. Bale, P. Chartrand, S. A. Degterov, G. Eriksson, K. Hack, R. Ben Mahfoud, J. Melançon, A. D. Pelton and S. Petersen: Calphad, 26(2002), 189-228. 